\title{
IgG myeloma presenting as ulcerative colitis
}

\author{
M. R. HAENEY, I. N. ROSS, R. A. THOMPSON, AND P. ASQUITH \\ From the Metabolic Unit and Regional Immunology Laboratory, East Birmingham Hospital, Birmingham, \\ B9 5ST, UK
}

SUMMARY Two patients who presented with ulcerative colitis are described. Both were found to have evidence of IgG monoclonal gammopathy and Bence-Jones proteinuria. This association has been reported previously only in the presence of myelomatous infiltration of the gastrointestinal tract or in amyloidosis, and hence the cases reported appear to be unique.

Although multiple myeloma may involve several organ systems, symptomatic involvement of the gastrointestinal tract is rare. In a major review of the presenting features of myeloma no mention was made of diarrhoea (Osserman, 1969), but occasional reports have documented gastrointestinal tract infiltration by solitary plasmacytoma and in multiple myeloma (Goldstein and Poker, 1966; Tangun et al., 1975). Conversely, cases have been described in which ulcerative colitis was accompanied by plasmacytosis (Fadem, 1952; Bernstein and Dixon, 1964) or by serum M-components (Röckl et al., 1964).

Two elderly patients presented with profuse bloody diarrhoea. Both were found to have features diagnostic of multiple myeloma. No infiltration of the intestine by atypical plasma cells or amyloidosis was demonstrated. In one instance, the diarrhoea responded to local steroid therapy, while in the other the gastrointestinal symptoms ameliorated during treatment of the dysgammaglobulinaemia with systemic steroids and cyclophosphamide. The purpose of this paper is to document the association of ulcerative colitis and myeloma.

\section{Case reports}

CASE 1

A 63-year-old Pakistani man, resident in England since 1969, presented in April 1974 with a six-month history of bloody diarrhoea. Other than evidence of weight loss clinical examination was normal but sigmoidoscopy to $17 \mathrm{~cm}$ showed a uniformly oedematous, hyperaemic rectal mucosa with mucus and contact bleeding. A biopsy was taken at $15 \mathrm{~cm}$.

Received for publication 10 March 1977
Investigations

The following investigations were normal: haemoglobin, absolute values for white cell count and $\mathbb{D}$ differential, serum folate, serum vitamin $B_{12}$, serum iron and total iron binding capacity, and haemoglobin electrophoretic pattern. However, the $\mathbb{\Phi}$ ESR ranged from 26 to $51 \mathrm{~mm} / \mathrm{h}$.

The blood urea, serum electrolytes, serum calciun $\vec{\theta}$ phosphate, alkaline phosphatase, and liver function tests, including total serum protein $(85 \mathrm{~g} / 1)$ and serum albumin $(47 \mathrm{~g} / \mathrm{l})$, were normal, while the serum orosomucoid ranged from 0.6 to $1.6 \mathrm{~g} / 1$ (NR 0.3-1.2 g/1).

Stool examinations showed no ova, cysts, para- $\stackrel{\square}{\square}$ sites or abnormal pathogens; Widal reactions to $\overrightarrow{\overrightarrow{0}}$ Salmonella typhi, paratyphi A,B,C, and non-specific 3 Salmonellae and fluorescent antibody tests to Schistosoma mansoni and Entamoeba histolytica? were negative. Microscopy of the jejunal aspirate showed no cysts of Giardia lamblia but Escherichia coli was cultured from the fluid.

The results of immunological, histological and radiological investigations are shown in the Table.

The stool, which was fluid and contained blood, ranged in volume from 650 to $1500 \mathrm{ml} / \mathrm{day}$. Although 을 initially normal, faecal fat and lactic acid excretion $\frac{D}{O}$ increased to a mean $35 \mathrm{mmol} /$ day and $55.6 \mathrm{mmol} / \mathrm{O}$. day respectively. Stool sodium loss and faecal o nitrogen excretion were also raised. Xylose and double isotope Schilling tests were normal. A jejunal $\mathrm{O}^{\circ}$ biopsy showed minor blunting of villi and a slight $\omega$ increase in inflammatory cells but immunofluorescence was normal.

Progress (Fig. 1)

Initially he was given salazopyrine and steroid retention enemata only. However, the total serum $\bar{D}$ IgG level, as measured by radial immunodiffusion, $\frac{\Omega}{\mathbb{D}}$ 
Table Immunological, radiological, and histological features of cases 1 and 2 at presentation

\begin{tabular}{|c|c|c|}
\hline Investigations & Case 1 & Case 2 \\
\hline \multicolumn{3}{|l|}{ Immunology } \\
\hline *Serum IgG (g/l) & $15 \cdot 90(\mathrm{NR} 6 \cdot 0-16.0 \mathrm{~g} / 1)$ & $22 \cdot 10$ \\
\hline IgA & $2 \cdot 41($ NR $0 \cdot 75-5 \cdot 20)$ & 0.54 \\
\hline IgM & $0.86(\mathrm{NR} 0.30-1 \cdot 80)$ & $0 \cdot 32$ \\
\hline Immunoelectrophoresis & Monoclonal IgG band & Monoclonal IgG band \\
\hline $\begin{array}{l}\text { †Electrophoretic densitometry on } \\
\text { M-band (g/l) }\end{array}$ & $12 \cdot 3$ & $12 \cdot 0$ \\
\hline ‡Urine & Free monoclonal light chains (kappa) & Free monoclonal light chains (lambda) \\
\hline $\begin{array}{l}\text { Radiology } \\
\text { Skeletal survey }\end{array}$ & No osteolytic lesions & No osteolytic lesions \\
\hline $\begin{array}{l}\text { Skeletal survey } \\
\text { Barium enema }\end{array}$ & Loss of sigmoid mucosal pattern. Poorly & $\begin{array}{l}\text { No osteolytic lesions } \\
\text { As Case } 1\end{array}$ \\
\hline & distensible rectum. Increased rectosigmoid space & \\
\hline Barium follow-through & $\begin{array}{l}\text { Single duodenal diverticulum. Multiple upper } \\
\text { jejunal diverticula }\end{array}$ & Normal \\
\hline \multicolumn{3}{|c|}{ 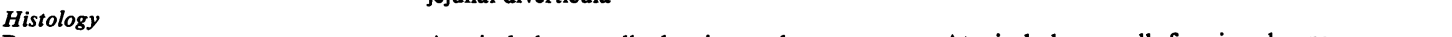 } \\
\hline Bone marrow & $\begin{array}{l}\text { Atypical plasma cells showing nuclear } \\
\text { immaturity. Immunofluorescence (IF):18-20\% } \\
\text { IgG staining plasma cells but }<1 \% \text { IgM and } \\
\text { IgA staining cells }\end{array}$ & $\begin{array}{l}\text { Atypical plasma cells forming clumps. } \\
\text { Multinucleate pleomorphic plasma cells with } \\
\text { prominent nucleoli. IF:10\% IgG staining plasma } \\
\text { cells }\end{array}$ \\
\hline Rectal biopsy & $\begin{array}{l}\text { Non-specific proctitis. Infiltration by lympho- } \\
\text { cytes and polymorphonuclear leucocytes. } \\
\text { Plasma cells morphologically normal. IF: } \\
\text { Ig staining plasma cells present IgA > IgG } \\
>>\text { IgM }\end{array}$ & $\begin{array}{l}\text { Active non-specific proctitis. Increased } \\
\text { cellularity and polymorphonuclear leucocytes in } \\
\text { lamina propria. Early crypt abscess formation. } \\
\text { No evidence of amyloid }\end{array}$ \\
\hline
\end{tabular}

* Total serum immunoglobulins were measured by single radial immunodiffusion.

TThe amount of paraprotein was estimated by scanning densitometry of the cellulose acetate electrophoretic strip.

$\ddagger$ Monoclonal free light chains were detected by their abnormal reactions on immunoelectrophoresis using specific anti-light chain antisera after first detecting a discrete band on cellulose acetate electrophoresis of concentrated urine.

reached $30 \mathrm{~g} / \mathrm{l}$ in six weeks with a progressive fall of serum IgA and IgM to 1.25 and $0.20 \mathrm{~g} / 1$ respectively. Electrophoretic densitometry of the $\mathbf{M}$ band also showed an increase to a peak of $26.9 \mathrm{~g} / 1$. These rapid changes were consistent with the diagnosis of an IgG myeloma rather than a benign monoclonal gammopathy. He was, therefore, started on cyclophosphamide, $5 \mathrm{mg} / \mathrm{kg}$ body weight per day, but, because of leucopenia, it was discontinued for three weeks and then given again at $2.5 \mathrm{mg} / \mathrm{kg}$ per day, together with oral prednisolone $40 \mathrm{mg} /$ day. On this combined therapy there was improvement in his diarrhoea, a fall in the serum IgG level, and a reduction in the size of the $\mathbf{M}$ band. Fluctuating steatorrhoea persisted and, because of radiological evidence of jejunal diverticulosis and the $E$. coli in the jejunal aspirate, he was treated with a two-week course of ampicillin. His further course and treatment are shown in Figure 1. Regular follow-up over 18 months has shown no deterioration in his clinical state, although adjustment of the chemotherapy dosage has been necessary from time to time. Usually he is maintained on cyclophosphamide, $100 \mathrm{mg}$, prednisolone, $5 \mathrm{mg}$, and salazopyrine, $1 \mathrm{~g}$, daily. On treatment repeated sigmoidoscopy has been normal while rectal biopsies have shown a slight increase in inflammatory cells but no abnormal plasma cells nor any evidence of amyloid.

CASE 2

A 61-year-old woman presented in January 1974 with a three-year history of weight loss and intermittent diarrhoea of increasing severity. She passed six liquid motions daily, the stool containing blood and mucus. She had not been abroad. Physical examination revealed a thin anaemic woman weighing $37 \mathrm{~kg}$ (est ideal wt $45 \mathrm{~kg}$ ). Abdominal and perianal examination was normal. Sigmoidoscopy to $18 \mathrm{~cm}$ showed a granular, oedematous rectal mucosa with mucopus and severe contact bleeding. A biopsy was taken at $13 \mathrm{~cm}$.

\section{Investigations}

Haemoglobin 9.2 g/dl; MCV $82 \mu^{3}$; MCH $28.5 \mathrm{pg}$; WBC $16.6 \times 10^{9} / 1$ with $80 \%$ neutrophils, $14 \%$ lymphocytes, $3 \%$ monocytes, and $3 \%$ eosinophils. ESR $75 \mathrm{~mm} / \mathrm{h}$. The serum folate and vitamin $\mathbf{B}_{12}$ were normal. Serum iron $2.5 \mu \mathrm{mol} / 1$; total iron binding capacity $59 \mu \mathrm{mol} / 1$.

Blood urea, serum electrolytes, serum calcium, phosphate, and alkaline phosphatase were normal. The serum orosomucoid was increased to between 2.2 and $3.0 \mathrm{~g} / \mathrm{l}$.

Stool examination showed no evidence of ova, cysts, parasites or abnormal pathogens.

Results of immunological, radiological, and histological investigations are shown in the Table.

Stool volumes averaged $1300 \mathrm{ml} / \mathrm{day}$. The stool was fluid and contained frank blood. Although faecal fat excretion was normal, the lactic acid excretion was increased to $16.7 \mathrm{mmol} /$ day. Faecal nitrogen and sodium excretions were also increased 


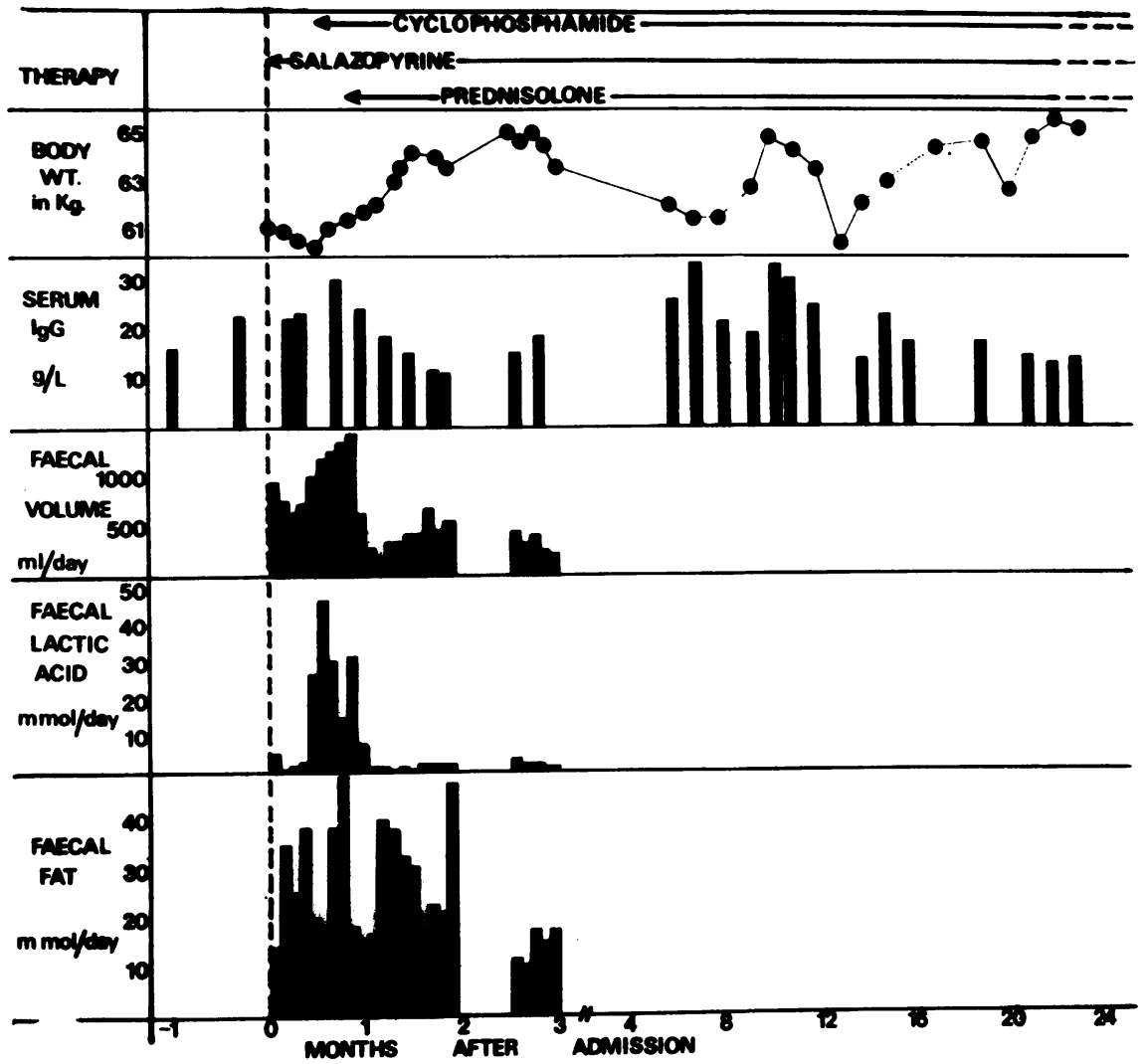

Fig. 1 Response of the $\lg G$ myeloma protein and intestinal function to therapy in case 1.

to $355 \mathrm{mmol} /$ day and $100 \mathrm{mmol} /$ day respectively. After a $5 \mathrm{~g}$ dose of xylose, only $14 \%$ was excreted in the five-hour period (NR $35 \% \pm 14 \%$ ).

\section{Progress (Fig. 2)}

The colitis was treated with salazopyrine and steroid retention enemata and the diarrhoea improved dramatically. No effect was seen on the paraproteinaemia but specific treatment was withheld.

In April 1974, she developed a right lower lobe pneumonia. The total serum IgG level was $21 \cdot 2 \mathrm{~g} / \mathrm{l}$, the paraprotein was $15.9 \mathrm{~g} / 1$ by densitometry, and there had been a significant decrease in serum IgA and IgM levels to $0.31 \mathrm{~g} / 1$ and $0.15 \mathrm{~g} / 1$ respectively. The patient was admitted for reassessment in September 1974. There had been no recurrence of diarrhoea or rectal bleeding but for six weeks she had been troubled by a salazopyrine-induced photosensitive eruption on exposed areas. Sigmoidoscopy to $20 \mathrm{~cm}$ was normal, a rectal biopsy being taken at $15 \mathrm{~cm}$. The histology of the biopsy was normal. The drug eruption resolved over three months and had not recurred 18 months later. During the follow-up period she has been clinically well and the total serum IgG level has tended to fall, although serum IgA and IgM levels are still suppressed. Free light chains are still present in the urine while electrophoretic densitometric values for the M-band have increased progressively to a level of $24 \mathrm{~g} / \mathrm{l}$ in February 1976.

\section{Discussion}

Both patients fulfil the accepted criteria for the diagnosis of myeloma (Galton and Peto, 1968; Medical Research Council, 1971, 1973). The diagnosis requires two of the following: (1) abnormal plasma cells in the bone marrow, (2) positive radiological findings of myelomatosis, (3) a monoclonal immunoglobulin in the serum, urine or both. Although a skeletal survey in both patients was normal, each had a monoclonal IgG serum para- 


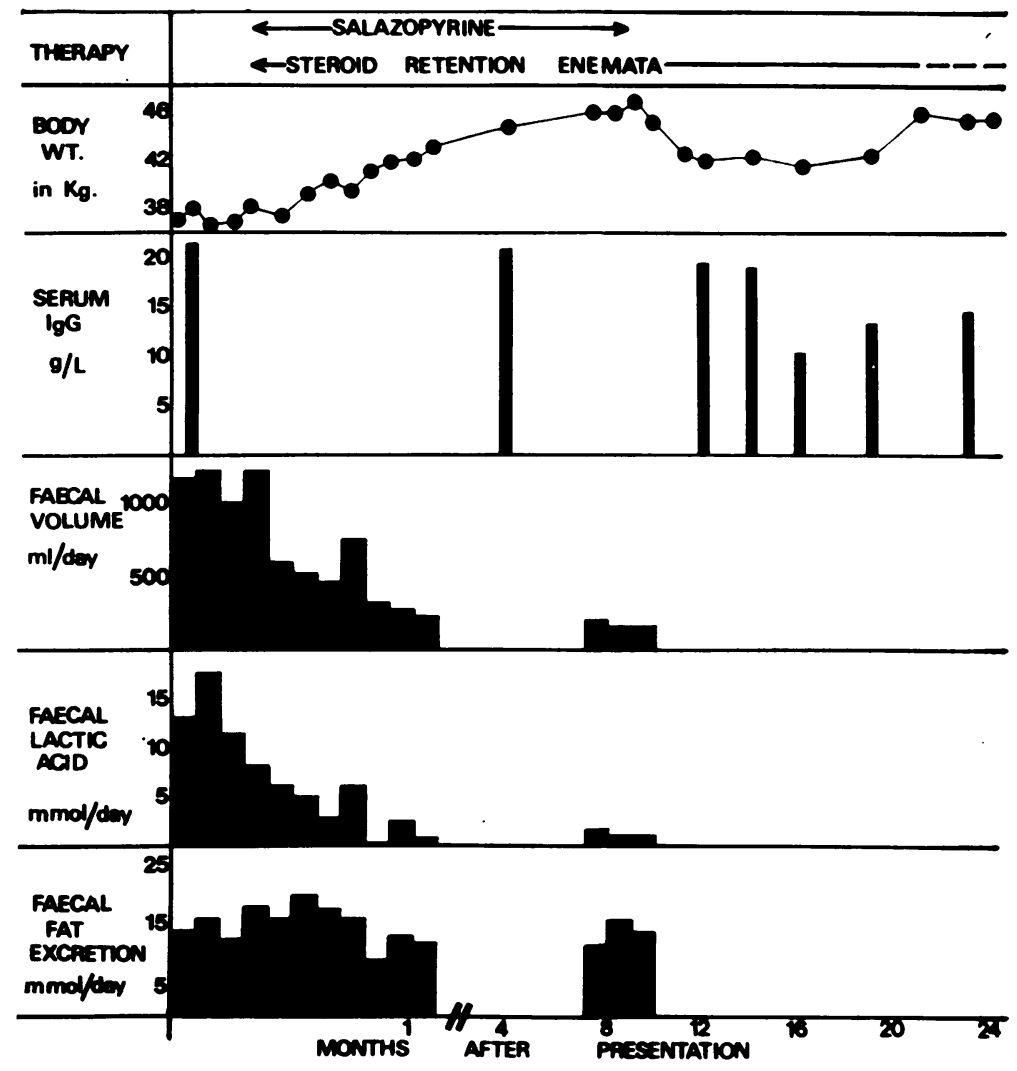

Fig. 2 Case 2 Response of the IgG myeloma protein and intestinal function to therapy.

protein with free light chains in the urine and atypical plasma cells in the bone marrow. The major diagnostic question is whether the patients had early multiple myeloma or 'benign' paraproteinaemia secondary to inflammatory bowel disease. Neither patient manifested the clinical and laboratory features of developed or advanced multiple myeloma (Pruzanski, 1976) and it is well recognised that benign paraproteins are relatively common in elderly patients (Zawadzki and Edwards, 1972; Kohn, 1974). The following parameters are most helpful in the differentiation of malignant from benign paraproteinaemia: (1) the absolute concentration of the paraprotein, (2) evidence of increasing serum concentration of the paraprotein, (3) suppression of normal immunoglobulin formation, (4) presence of significant amounts of Bence-Jones proteinuria, (5) a characteristic bone marrow picture, (6) results of the skeletal x-ray survey. The presence of at least three of the laboratory criteria can be regarded as indicative of malignancy (Kohn, 1974).

It has been stated that cytological examination of the bone marrow of a qualitative kind does not give much information regarding the benign or malignant nature of the condition (Waldenström, 1973). Indeed, the appearance of IgG-producing myeloma cells is generally considered to be that of typical, well differentiated or moderately differentiated plasmacytic cells (Azar, 1973). However, quantitative analysis is important and plasmacytosis in excess of $20 \%$ is usually an indication of malignancy (Zawadzki and Edwards, 1972).

Immunochemical techniques for the estimation of serum paraproteins, such as radial immunodiffusion, have the disadvantage that a polyclonal antiserum will react differently with various monoclonal proteins. Unreliability is also due to variations in molecular size, formation of complex aggregates, and idiotypic antigenicity (Hobbs et al., 1974). In the present study, total serum immunoglobulin levels were measured by radial immunodiffusion, but the inaccuracy of this method was controlled, as far as possible, by remeasuring previous samples from each patient when a new estimate was requested. The paraprotein was quantitated by 
electrophoretic densitometry (Kohn, 1973). BenceJones protein (free monoclonal light chains) was detected by immunoelectrophoresis using specific anti-k or anti- $\lambda$ antisera. The absence of reactivity with anti- $\gamma$ chain antiserum excluded renal glomerular leakage of paraprotein as the cause of the monoclonal reactions with the anti-light chain antisera. In both cases, Bence-Jones proteinuria was reported to be present in 'moderate' amounts by a semiquantitative assessment but, in our opinion, the unreliability of available methods does not allow a more accurate absolute quantitation to be made.

There can be little doubt regarding the malignancy of the process in the two cases described. In case 1, the marked plasmacytosis $(20 \%)$ coupled with the presence of atypical plasma cells showing nuclear immaturity is in keeping with this (Zawadzki and Edwards, 1972; Kohn, 1974) while, in case 2, the marrow picture is unhelpful in excluding reactive plasmacytosis. Both patients had paraprotein levels (by densitometry) of approximately $12 \mathrm{~g} / 1$ at presentation, but these have risen progressively to values of around $25 \mathrm{~g} / \mathrm{l}$. Paraprotein levels in excess of $20 \mathrm{~g} / 1$ are generally indicative of malignancy (Hobbs, 1967; Zawadzki and Edwards, 1972), as is the progressive rise in paraprotein concentration (Hobbs, 1971; Zawadzki and Edwards, 1972; Kohn, 1974). In case 1 , a doubling in the serum concentration of the M-component occurred over the course of a few weeks, while the second patient showed this same feature over an interval of many months accompanied by significant suppression of normal immunoglobulin production. Serum $\operatorname{IgA}$ and IgM also showed a downward trend in case 1. The presence of immunosuppression has been stressed as a very valuable diagnostic pointer of malignancy (Hobbs, 1967; Zawadzki and Edwards, 1972; Kohn, 1974). Monoclonal light chain components in the urine are a very ominous sign and have only rarely been observed in benign proteinaemia. In both the cases described in this report, there was 'moderate' Bence-Jones proteinuria. In our opinion, these patients had evidence of malignant paraproteinaemia but were detected early in the natural history of myeloma, corresponding to stage $I$ in the clinical staging system proposed by Durie and Salmon (1975). The clinical interest lies in their initial presentations with acute bloody diarrhoea, and the sigmoidoscopic, biopsy, and radiological features of ulcerative colitis.

Haemorrhagic colitis, ileocolitis, and proctitis have been recorded among the gastrointestinal complications of leukaemia (Prolla and Kirsner, 1964), lymphoma (Nugent et al., 1972), and lymphosarcoma (Cornes et al., 1961; Myerson et al., 1974). However, major reviews of proven myelomatosis and other monoclonal immunoglobulin disorders have not included nonspecific proctosigmoiditis as으 a significant feature of the clinical picture in any patient (Osserman, 1959; Owen et al., 1959; Michaux $\stackrel{\stackrel{D}{+}}{\circ}$ and Heremans, 1969; Williams et al., 1969; Axelssono and Hällen, 1972; Zawadzki and Edwards, 1972;흘 Talerman and Haije, 1973). Actual infiltration of the $\frac{\bar{s}}{\partial}$ gastrointestinal tract by myeloma cells may occur. $\stackrel{\mathbb{\Omega}}{\varrho}$ In a review of the literature, Goldstein and Poker (1966) recorded 46 cases of plasma cell neoplasia $\vec{P}$ involving the intestinal tract, of which 36 were? solitary plasmacytomas and 10 were cases of $\vec{\omega}$ multiple myeloma diagnosed from necropsy material. $\stackrel{5}{\circ}$ Rectal biopsies in our two patients showed no evi-웅 dence of abnormal plasma cells on routine histology $\dot{\omega}$ or immunofluorescence. Secondary amyloidosis 6 of the large bowel could also explain the proctosigmoiditis but this was excluded as far as possible $\stackrel{N}{N}$ by specific staining of the biopsy material. However, $\stackrel{\circ}{\supset}$ this technique does not exclude the possibility of amyloid infiltration of arterioles in the submucous $\mathscr{\Phi}$ layers (Campbell and Halford, 1964).

Specific documentation of an association between 'myeloma' and colitis is rare. Bernstein and Dixon (1964) reported a patient with ulcerative colitis who was initially diagnosed as having multiple myelor $\overrightarrow{0}$ matosis on the basis of a bone marrow plasmacytosas. of between $19.5 \%$ and $21.5 \%$. There was no radiological evidence of myeloma and no evidence of a monoclonal immunoglobulin in serum or urine. Although this patient would not satisfy the present criteria of myeloma, the absence of a paraprotein $\mathbb{\perp}$ might have been due to the relatively unsophisticated $\stackrel{2}{\vec{A}}$ methods of serum and urine analysis available at that time. The degree of plasmacytosis seen in their patient is in favour of a malignant process although not diagnostic in its own right (Zawadzki and Edwards, 1972; Kohn, 1974). Röckl et al. (1964) 융 noted that $30-40 \%$ of a series of patients with pyoderma gangrenosum also had ulcerative colitis. They investigated six patients and found that four had M-components on electrophoresis. These subjects had increased IgA levels but there was no 은 detailed investigation of the pathological protein. $\rightarrow$ In one patient who died, it was shown that the bone marrow was infiltrated with plasma cells and $N$ this patient also had Bence-Jones proteinuria.

Because the aetiology of ulcerative colitis is 0 unknown, it is difficult to speculate about the $\underset{\mathrm{N}}{N}$ relationship between the IgG myeloma and the ulcerative colitis in the two patients. Symptoms of 0 colitis have been reported in a few patients with $\frac{\widetilde{D}}{D}$ primary humoral immunodeficiency syndromes $\stackrel{\circ}{+}$ (Ochs and Ament, 1976). Colitis was associated in 7 some patients with malabsorption, indicating that both small and large intestines were involved, 
whereas the absence of malabsorption in other patients suggests that disease was restricted to the colon (Ochs and Ament, 1976). As IgG myeloma patients have decreased resistance to infection, including that at mucosal surfaces, it is possible that defective local antibody production increases the potential for invasion by hypothetical microorganisms. If this were so, one would expect treatment of the myeloma to be accompanied by improvement in the gastrointestinal disease. This seemed to occur in case 1.

On a practical basis it is suggested that the diagnosis of myelomatosis should be considered in elderly patients presenting with ulcerative colitis.

\section{References}

Axelsson, U., and Hällen, J. (1972). A population study on monoclonal gammopathy. Acta Medica Scandinavica, 191, 111-113.

Azar, H. A. (1973). The myeloma cell. In Multiple Myeloma and Related Disorders, edited by H. A. Azar and M. Potter, Chapter 2, pp. 86-152. Harper and Row, New York and London.

Bernstein, J. S., and Dixon, D. D. (1964). Ulcerative colitis disguised as multiple myeloma. American Journal of Digestive Diseases, 9, 625-633.

Campbell, A. M. G., and Halford, M. E. H. (1964). Syndrome of diarrhoea and peripheral nerve changes due to generalised vascular disease. British Medical Journal, 2, 1509-1510.

Cornes, J. S., Smith, J. C., and Southwood, W. F. W. (1961). Lymphosarcoma in chronic ulcerative colitis with report of 2 cases. British Journal of Surgery, 49, 50-53.

Durie, B. G. M., and Salmon, S. E. (1975). A clinical staging system for multiple myeloma: correlation of measured myeloma cell mass with presenting clinical features, response to treatment, and survival. Cancer, 36, 842-854.

Fadem, R. S. (1952). Differentiation of plasmocytic responses from myelomatous diseases on the basis of bone-marrow findings. Cancer (Philad.), 5, 128-137.

Galton, D. A. G., and Peto, R. (1968). A progress report on the Medical Research Council's therapeutic trial in myelomatosis (abstract). British Journal of Haematology, 15, 319-320.

Goldstein, W. B., and Poker, N. (1966). Multiple myeloma involving the gastrointestinal tract. Gastroenterology, 51, 87-93.

Hobbs, J. R. (1967). Paraproteins, benign or malignant? British Medical Journal, 3, 699-704.

Hobbs, J. R. (1971). Immunocytoma o' mice an' men. British Medical Journal, 2, 67-72.

Hobbs, J. R., Carter, P. M., Cooke, K. B., Foster, M., and Oon, C. J. (1974). IgM paraproteins. Journal of Clinical Pathology, 28, Supplement Ass. clin. Path., 6, 54-64.

Kohn, J. (1973). The laboratory investigation of paraproteinaemia. In Recent Advances in Clinical Path- ology, Series 6, edited by S. C. Dyke et al., pp. 363-401. Churchill Livingstone, Edinburgh and London.

Kohn, J. (1974). Benign paraproteinaemias. Journal of Clinical Pathology, 28, Supplement 6, 77-82.

Medical Research Council (1971). Myelomatosis: Comparison of melphalan and cyclophosphamide therapy. British Medical Journal, 1, 640-641.

Medical Research Council (1973). Report of the First Myelomatosis Trial Part I. Analysis of presenting features of prognostic importance. British Journal of Haematology, 24, 123-139.

Michaux, J. L., and Heremans, J. F. (1969). Thirty cases of monclonal immunoglobulin disorders other than myeloma or macroglobulinemia. American Journal of Medicine, 46, 562-579.

Myerson, P., Myerson, D., Miller, D., DeLuca, V. A., Jr., and Lawson, J. P. (1974). Lymphosarcoma of the bowel masquerading as ulcerative colitis. Diseases of the Colon and Rectum, 17, 710-715.

Nugent, F. W., Zuberi, S., Bulan, M. B., and Legg, M. A. (1972). Colonic lymphoma in ulcerative colitis. Lahey Clinic Foundation Bulletin, 21, 104-111.

Ochs, H. D., and Ament, M. E. (1976). Gastrointestinal tract and immunodeficiency. In: Immunological Aspects of the Liver and Gastrointestinal Tract, edited by A. Ferguson and R. N. M. MacSween, pp. 83-120. MTP Press, Lancaster.

Osserman, E. F. (1959). Plasma-cell myeloma. II, Clinical aspects. New England Journal of Medicine, 261, 952960.

Owen, J. A., Pitney, W. R., and O'Dea, J. F. (1959). "Myeloma" serum electrophoretic patterns in conditions other than myelomatosis. Journal of Clinical Pathology, 12, 344-350.

Prolla, J. C., and Kirsner, J. B. (1964). The gastrointesinal lesions and complications of the leukaemias. Annals of Internal Medicine, 61, 1084-1103.

Pruzanski, W. (1976). Clinical manifestations of multiple myeloma: relation to class and type of $\mathbf{M}$ component. Canadian Medical Association Journal, 114, 896-897.

Röckl, H., Knedel, M., and Schröpl, F. (1964). Quoted by Waldenström, J. G. (1973).

Talerman, A., and Haije, W. G. (1973). The frequency of M-components in sera of patients with solid malignant neoplasms. British Journal of Cancer, 27, 276-282.

Tangun, Y., Saracbasi, Z., Inceman, S., Danon, F., and Seligmann, M. (1975). IgA myeloma globulin and Bence-Jones proteinuria in diffuse plasmacytoma of small intestine (Letter). Annals of Internal Medicine, 83, 673 .

Waldenström, J. G. (1973). Benign monoclonal gammapathies. In Multiple Myeloma and Related Disorders, edited by H. A. Azar and M. Potter. Chapter 5, pp. 247-286. Harper and Row, New York and London.

Williams, R. C., Jr., Bailly, R. C., and Howe, R. B. (1969). Studies of 'benign' serum M-components. Americal Journal of Medical Science, 257, 275-293.

Zawadzki, Z. A., and Edwards, G. A. (1972). Nonmyelomatous monoclonal immunoglobulinemia. In Progress in Clinical Immunology, edited by R. S. Schwartz, Vol. 1, pp. 105-156. Grune and Stratton, New York and London. 